\title{
Effects of Temperature and Chromium (III) Ion on the Structure of Bovine $\beta$-Lactoglobulin-A
}

\author{
Adeleh Divsalar, ${ }^{*, a, b}$ Ali Akbar Saboury, ${ }^{a}$ Faizan Ahmad ${ }^{c}$ and Ali Akbar Moosavi-Movahedi ${ }^{a}$ \\ ${ }^{a}$ Institute of Biochemistry and Biophysics, University of Tehran, Tehran, Iran \\ ${ }^{b}$ Department of Biological Sciences, Tarbiat Moallem University, Tehran, Iran \\ ${ }^{c}$ Department of Bioscience, Jamia Millia Islamia, New Delhi, India
}

\begin{abstract}
Estudos termodinâmicos relativos ao efeito da temperatura (de 27 a $47^{\circ} \mathrm{C}$ ) sobre a estrutura da b-lactoglobulina-A bovina (BLG-A), em solução de cloreto de sódio $50 \mathrm{mmol} \mathrm{L}^{-1}$, na presença e ausência de íons $\mathrm{Cr}(\mathrm{III})$, usando espectroscopia de absorção no UV-Visível, dicroísmo circular (DC), próximo e distante e, espectroscopia de fluorescência, foram realizados. Os estudos com CD UV-distante, a diferentes temperaturas e na presença e ausência de íons Cr(III) não mostraram alteração significativa na estrutura secundária da proteína. Ao contrário, os estudos empregando DC UV-próximo evidenciaram alterações na estrutura terciária da BLG natural com o aumento da temperatura, indicada pela exposição de fragmentos de tirosina (Tyr). Estudos de espectroscopia de fluorescência em BLG-A natural, na ausência e presença de íons Cr(III) apresentam considerável alteração na estrutura terciária da proteína, devido ao aumento da temperatura. Com a estabilização da proteína na presença de íons Cr(III), a estrutura terciária da BLG revela considerável alterações a 37 e $47^{\circ} \mathrm{C}$ as quais são concordantes com o aumento nos valores de $\mathrm{T}_{\mathrm{m}}$ nestas temperaturas.
\end{abstract}

Thermodynamic studies of the effect of temperature $\left(27-47^{\circ} \mathrm{C}\right)$ on the structure of bovine $\beta$-lactoglobulin-A (BLG-A) in the absence and presence of $\mathrm{Cr}$ (III) containing $50 \mathrm{mmol} \mathrm{L}^{-1}$ sodium chloride have been carried out using UV-Visible absorption spectroscopy, far and near circular dichroism (CD) and fluorescence spectroscopy. The far-UV CD studies do not show any significant change in the secondary structure of the protein at different temperatures in the absence and presence of $\mathrm{Cr}(\mathrm{III})$. On the contrary, the near-UV CD studies show change in the tertiary structure of the native BLG on increasing the temperature, indicating the exposure of Tyr residues. Fluorescence spectroscopic studies on the native BLG-A in the absence and presence of $\mathrm{Cr}$ (III) represent considerable change in the tertiary structure of the protein due to the increase in temperature. Due to protein stabilization in the presence of $\mathrm{Cr}$ (III) ions, the tertiary structure of BLG represents considerable alterations at 37 and $47^{\circ} \mathrm{C}$ that is in agreement with increasing of $\mathrm{T}_{\mathrm{m}}$ values at these temperatures.

Keywords: $\beta$-lactoglobulin, temperature, $\mathrm{Cr}(\mathrm{III})$ ions, tertiary structure, $\mathrm{T}_{\mathrm{m}}$ value

\section{Introduction}

Whey protein products are important food ingredients because of their desirable functional properties such as gelation and emulsification. The major proteins in these whey protein products are $\alpha$-lactalbumin ( $\alpha$-La; 20\%) and $\beta$-lactoglobulin (BLG; 50\%). ${ }^{1} \beta$-Lactoglobulin is a small water-soluble protein that forms the major component of ruminant milk whey. ${ }^{2}$ Seven different genetic variants have been identified but in industrial preparations A and B variants are the most prevalent. Variant A (BLG-A) differs

\footnotetext{
*e-mail: divsalar@ibb.ut.ac.ir
}

in amino acid sequence from variant $\mathrm{B}$ (BLG-B) at positions $64\left(\mathrm{Asp}_{\mathrm{A}} \rightarrow \mathrm{Gly}_{\mathrm{B}}\right)$ and $118\left(\mathrm{Val}_{\mathrm{A}} \rightarrow \mathrm{Ala}_{\mathrm{B}}\right){ }^{3}{ }^{3}$ These differences result in distinct biophysical and biochemical properties of the variants such as heat stability, self-association properties and solubility. ${ }^{4,5}$

BLG is a member of the lipocalin superfamily of transporter molecules for small hydrophobic ligands. Some examples of additional members of this protein superfamily include apolipoprotein $\mathrm{D}$, retinol-binding protein, bilinbinding protein, insecticyanin, odorant binding protein and tear lipocalins. Although they show low sequence similarity, generally less than $20 \%$ identity, their remarkably similar topology consisting of eight strands of antiparallel $\beta$-sheet 
twisted into a cone-shaped barrel, indicates their evolution from a common ancestor. ${ }^{2}$

BLG interacts strongly with various hydrophobic ligands such as fatty acids, ${ }^{6}$ hemin, ${ }^{7}$ ellipticine, ${ }^{8}$ aromatic hydrocarbons, ${ }^{9}$ and carcinogenic hydrocarbons. ${ }^{10}$ This protein is one of the few proteins, which bind sodium ions. Maximum number of $\mathrm{Na}^{+}$bound per molecule of $\mathrm{BLG}$ (A and B) is four. ${ }^{11}$ Studies show that $\mathrm{Hg}^{2+}$ leads to the formation of an insoluble aggregate at high $\mathrm{pH}$ in BLG . ${ }^{2}$

Metal ions play important roles in many biological systems for example, currently, at least one- third of all proteins appear to contain metal ions and all ribozymes (RNA enzymes) appear to be metalloenzymes. Naturally occurring metal ions add extra dimensions to the properties of proteins and ribozymes, which otherwise are constrained by finite number of building blocks that make up their primary structures. ${ }^{12}$

Trace elements, including the essential and the toxic, play an important role in the life and environmental sciences; one of them is chromium (Cr) ${ }^{13}$ Chromium is an important transition metal ion with diverse industrial applications and is an essential micronutrient required to promote the action of insulin in body tissues so that the body can use sugars, proteins and fats. ${ }^{14}$ Two of the most important oxidation states of chromium are $\mathrm{Cr}$ (III) and $\mathrm{Cr}$ (VI). ${ }^{14}$ The major non-occupational source of chromium for humans is food such as vegetables, meat, urban air and cigarettes. ${ }^{15}$ The reduction of $\mathrm{Cr}$ (VI) to $\mathrm{Cr}$ (III) results in the formation of reactive intermediates that contribute to the cytotoxicity, genotoxicity and carcinogenicity of $\mathrm{Cr}$ (VI) containing compounds. ${ }^{14}$ The formation of reactive intermediates that together with oxidative stress and oxidative tissue damage and a cascade of cellular events including modulation of apoptosis regulatory gene P53 contribute to the cytotoxicity, genotoxicity and carcinogenicity of $\mathrm{Cr}$ (VI) containing compounds. $\mathrm{Cr}^{6+}$ has been shown to be carcinogenic and mutagenic to biological system. ${ }^{13,14}$ On the contrary, $\mathrm{Cr}^{3+}$ salts such as chromium polynicotinate, chromium chloride and chromium picolinate are used as micronutrients and nutritional supplements and have been demonstrated to exhibit a significant number of health benefits in animals and human. ${ }^{16} \mathrm{The} \mathrm{Cr}$ deficiency includes symptoms resembling diabetes, such as glucose intolerance impairment with the requirement of increasing insulin, etc, and $\mathrm{Cr}$ supplement can alleviate these symptoms. However, up to now, the biological function of $\mathrm{Cr}$ in an organism is still unclear and the concentration of $\mathrm{Cr}$ in many biological materials is usually at an ultra trace level. ${ }^{13}$ The epidemiological studies show that the $\mathrm{Cr}^{6+}$ causes increased risk of bone, prostate, lymphomas, Hodgkin's, leukemia, stomach, genital, renal, and bladder cancer, reflecting the ability of $\mathrm{Cr}^{6+}$ to penetrate all tissues in the body. ${ }^{17}$ However, the reactivity of $\mathrm{Cr}$ (III) can be tuned by complexing the metal ion with appropriate ligand such as in the case of $\left[\mathrm{Cr}(\mathrm{salen})\left(\mathrm{H}_{2} \mathrm{O}\right)\right]\left(\mathrm{ClO}_{4}\right)$. This complex, unlike other $\mathrm{Cr}$ (III) complexes undergoes facile aqua ligand substitution due to ground state structural distortion. ${ }^{16} \mathrm{Cr}^{3+}$ complexes in proper ligand environment have been shown to induce chromosomal aberrations, mutagenicity in Salmonella bacteria (S. typhimurium), cytotoxicity and genotoxicity in cell lines. ${ }^{17}$ Direct effects on protein and DNA have been shown in terms of DNA-protein cross-linking, DNA scission, plasmid cleavage and protein cleavage. ${ }^{13-17}$ The relative importance of the chromium ions and of the free oxidizing radicals that may generate in causing cancers and allergic sensitization remain to be elucidated. Our previous studies showed that $\mathrm{Cr}^{3+}$ could bind to BLG-A, and the number of binding sites for the metal ion on BGL-A and the binding strength have been reported.$^{18}$ In this study, we investigate the effect of different temperatures, 27, 37, 42 and $47^{\circ} \mathrm{C}$, on the structure of the native BLG-A, a carrier protein, in the presence and absence of $\mathrm{Cr}^{3+}$.

\section{Experimental}

\section{Chemicals}

Bovine $\beta$-lactoglobulin (BLG-A) was obtained from Sigma Chemical Company (USA). Chromiun(III) nitrate was purchased from Merck and ANS (1- anilinonaphthalene8 -sulfonate) was purchased from Sigma. All other materials and reagents were of analytical grade, and solutions were made in double-distilled water. $50 \mathrm{mmol} \mathrm{L}^{-1} \mathrm{NaCl}$ solution was used as solvent. Concentrations of BLG-A were determined spctrophotometrically using a value of $17,600 \mathrm{~mol}^{-1} \mathrm{~L} \mathrm{~cm}^{-1}$ for the molar absorption coefficient at $287 \mathrm{~nm}^{19}$

\section{UV absorption measurements}

Change in the absorbance of the native BLG-A solution $\left(0.29 \mathrm{mg} \mathrm{mL}^{-1}\right)$ at $280 \mathrm{~nm}$ upon titration by aliquots of a fixed stock concentration of $\mathrm{Cr}^{3+}$ ion $\left(10 \mathrm{mmol} \mathrm{L}^{-1}\right)$ at different temperatures $\left(27,37,42\right.$ and $\left.47^{\circ} \mathrm{C}\right)$ were measured in the UV-Visible spectrophotometer, Shimadzu-3100 instrument (Kyoto, Japan). BLG-A and Cr (III) nitrate were dissolved

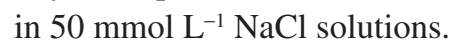

\section{Fluorescence measurements}

Fluorescence intensity measurements were carried out on a Hitachi spectrofluorimeter model MPF-4 (Japan). The excitation wavelength was adjusted at $290 \mathrm{~nm}$ and 
the emission spectra were recorded for all samples at different temperatures $\left(27,37,42\right.$ and $\left.47{ }^{\circ} \mathrm{C}\right)$ in the range of $300-470 \mathrm{~nm}$. The binding of a hydrophobic fluorescent probe, ANS to BLG-A was monitored by exciting the ANS at $350 \mathrm{~nm}$ and recording the emission spectra in the range of 400-600 nm. Measurements were made in a $1 \mathrm{~cm}$ path length fluorescence cuvette. Samples of $5 \mu \mathrm{mol} \mathrm{L}{ }^{-1} \mathrm{BLG}-\mathrm{A}$ was in $50 \mathrm{mmol} \mathrm{L}^{-1}$ sodium solution.

\section{Circular dichroism (CD) measurements}

CD spectra were recorded in an Aviv Spectropolarimeter model 215 (USA). Changes in the secondary structure and tertiary structure of BLG-A were monitored in the far-UV region (200-260 nm) using $1 \mathrm{~mm}$ path length cell and in the near-UV region (260-320 nm) using $1 \mathrm{~cm}$ path length cell. The protein concentration in the experiments for far UV region was $13.5 \mu \mathrm{mol} \mathrm{L} \mathrm{L}^{-1}$ and for near UV region was $57 \mu \mathrm{mol} \mathrm{L} \mathrm{L}^{-1}$. The results were expressed in mean residue ellipticity $[\theta]\left(\mathrm{deg} \mathrm{cm}^{2} \mathrm{dmol}^{-1}\right)$ based on a mean aminoacid residue weight of 114 (MRW). ${ }^{18}$ The mean residue ellipticity was determined as

$$
[\theta]_{\lambda}=\left(100 \times \mathrm{MRW} \times \theta_{\text {obs }} \times(\mathrm{cl})^{-1}\right)
$$

where $\theta_{\mathrm{obs}}$ is the observed ellipticity in degrees at a given wavelength, $c$ is the protein concentration $\left(\mathrm{mg} \mathrm{mL}^{-1}\right)$ and $l$ is the length of the light path $(\mathrm{cm})$. The CD software was used to predict the secondary structure of the protein according to the statistical method. ${ }^{20-21}$

In the temperature-scanning near UV-CD studies, changes in ellipticity at $293\left([\theta]_{293}\right)$ versus temperature, which describe the thermal denaturation of BLG-A in the presence of different concentrations of $\left[\mathrm{Cr}^{3+}\right]_{1 / 2}$ (resulted of denaturation studied by UV-Visible spectroscopy) were obtained. $\left[\mathrm{Cr}^{3+}\right]_{1 / 2}$ is the concentrations of $\mathrm{Cr}^{3+}$ in the midpoint of transition. The protein concentration in these experiments was $57 \mu \mathrm{mol} \mathrm{L}{ }^{-1}$.

\section{Results and Discussion}

\section{$U V$-absorption measurements}

The aminoacid residue responsible for the major absorbance of proteins in the near-UV region is Trp, with a maximum at $c a .280 \mathrm{~nm} .{ }^{22}$ Figure 1 shows the absorbance change at $280 \mathrm{~nm}$ of BLG-A upon titration by aliquots of a fixed stock concentration of $\mathrm{Cr}^{3+}$ ion $\left(10 \mathrm{mmol} \mathrm{L}^{-1}\right)$ at different intentionally chosen temperatures of 27 (room temperature), 37 (physiologic temperature), 42 (fever temperature) and $47^{\circ} \mathrm{C}$ (upper the fever temperature). At $27^{\circ} \mathrm{C}$, as the aliquot solutions of $\mathrm{Cr}^{3+}$ ion are increased in the titration mixture, the absorbance of the protein did not change. On the other hand, $\mathrm{Cr}^{3+}$ ion induces significant change in $\varepsilon_{280}$ at higher temperatures. The values of $\left[\mathrm{Cr}^{3+}\right]_{1 / 2}$, the midpoint of transition, were estimated, which are given in Table 1. It seems in this table that $\left[\mathrm{Cr}^{3+}\right]_{1 / 2}$ deceases with an increase in temperature. In order to evaluate the effect of $\mathrm{Cr}$ ion on the protein stability, it was estimated the free energy of chemical unfolding using Pace's analysis. ${ }^{23}$ In brief, it is assumed that the $\mathrm{Cr}$ ion-induced denaturation is a two-state process (equation 1),

Table 1. Thermodynamic parameters of BLG-A under different solvent conditions

\begin{tabular}{lccc}
\hline Temperature $/{ }^{\circ} \mathrm{C}$ & ${ }^{\mathrm{a}}\left[\mathrm{Cr}^{3+}\right]_{1 / 2} / \mu \mathrm{mol} \mathrm{L}^{-1}$ & $\begin{array}{c}{ }^{\mathrm{b}} \Delta \mathrm{G}_{\mathrm{H} 20}^{\circ} \\
\mathrm{kJ} \mathrm{mol}^{-1}\end{array}$ & ${ }^{\mathrm{c}} \mathrm{T}_{\mathrm{m}} /{ }^{\circ} \mathrm{C}$ \\
\hline 27 & 224.2 & - & 83 \\
37 & 130.3 & 23.0 & 85 \\
42 & 72.7 & 24.0 & 84 \\
47 & 36.8 & 20.8 & 88 \\
Native BLG at 27 & - & - & 86 \\
\hline
\end{tabular}

${ }^{\mathrm{a}}$ The midpoint concentrations of $\mathrm{Cr}^{3+}$, ${ }^{\mathrm{b}}$ the stability value of the protein in the absence of denaturant $\left(\mathrm{Cr}^{3+}\right)$ and ${ }^{\mathrm{c}}$ the value of melting temperature.

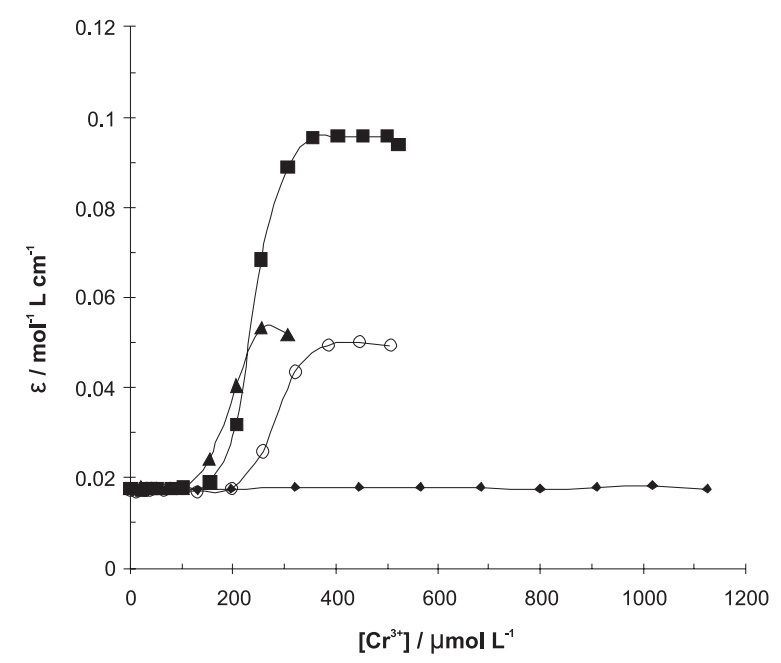

Figure 1. Change in molar absorption coefficient at $280 \mathrm{~nm}$ upon titration of a $1.5 \mathrm{~mL}$ BLG-A solution in $50 \mathrm{mmol} \mathrm{L}^{-1}$ sodium chloride solution $(\mathrm{pH} 7.0)$ at $27(\bullet), 37(\mathrm{O}), 42(\boldsymbol{\square})$ and $47^{\circ} \mathrm{C}(\boldsymbol{\Delta})$ with increasing aliquots of a fixed stock concentration of $\mathrm{Cr}^{3+}$ ion $\left(10 \mathrm{mmol} \mathrm{L}^{-1}\right)$.

Native $(\mathrm{N}) \Leftrightarrow$ Denatured (D)

This process was described as a single denaturantdependent step according to the two-step theory. ${ }^{24-26}$ Each transition curve shown in Figure 1 was analyzed for $F_{d}$, the denatured fraction, and $\mathrm{K}_{\mathrm{D}}$, the equilibrium constant of denaturation using the relations, showed in equations 2 and 3 , respectively: 
$F_{d}=\frac{\left(Y_{N}-Y_{o b s}\right)}{\left(Y_{N}-Y_{D}\right)}$

$\mathrm{K}_{\mathrm{D}}=\frac{\mathrm{F}_{\mathrm{d}}}{\left(1-\mathrm{F}_{\mathrm{d}}\right)}=\frac{\left(\mathrm{Y}_{\mathrm{N}}-\mathrm{Y}_{\mathrm{obs}}\right)}{\left(\mathrm{Y}_{\mathrm{obs}}-\mathrm{Y}_{\mathrm{D}}\right)}$

where $\mathrm{Y}_{\mathrm{obs}}$ is the observed variable parameter (e.g. absorbance) and $\mathrm{Y}_{\mathrm{N}}$ and $\mathrm{Y}_{\mathrm{D}}$ are the values of $\mathrm{Y}$ characteristics of the fully native and denatured conformation, respectively. The $\Delta \mathrm{G}^{\circ}$ change is given by the following equation 4 :

$\Delta \mathrm{G}^{\circ}=-\mathrm{RT} \ln \mathrm{K}_{\mathrm{D}}$

where $\mathrm{R}$ is the universal gas constant, and $\mathrm{T}$ is the absolute temperature. $\Delta G_{\mathrm{H}_{2} \mathrm{O}}^{0}$ varies linearly with denaturant concentration over a limited region. The simplest method of estimating the conformational stability of the protein in the absence of denaturant, is to assume that $\Delta G_{\mathrm{H}_{2} \mathrm{O}}^{0}$ versus denaturant concentration in the transition region is a linear plot. ${ }^{27}$ The $\Delta G_{H_{2} O}^{0}$ values obtained from the linear extrapolation (Figure 2) are given in Table 1. This table shows that the $\Delta G_{\mathrm{H}_{2} \mathrm{O}}^{0}$ values of the native BLG-A at $42^{\circ} \mathrm{C}$ are greater than those of the protein at $37{ }^{\circ} \mathrm{C}$ and $47^{\circ} \mathrm{C}$ (approximately 1.0 and $3.2 \mathrm{~kJ} \mathrm{~mol}^{-1}$, respectively). Previous reports represented that BLG denatured via three-state dissociation coupled unfolding (DCU) process involving the formation of stable monomer as intermediate; dimer $\Leftrightarrow$ monomer $\Leftrightarrow$ unfolding state. The Gibbs free energy change for denaturing BLG $\left(\Delta \mathrm{G}^{\circ} \mathrm{DCU}\right)$ obtained by Apenten ${ }^{28}$ calculated $60.0 \mathrm{~kJ} \mathrm{~mol}^{-1}$ at $\mathrm{pH} 7.0$ and $72.0 \mathrm{~kJ} \mathrm{~mol}^{-1}$ at $\mathrm{pH} 2.6$. By comparison, the dissociation free energies of dimeric BLG are 23.0, 24.0 and $20.8 \mathrm{~kJ} \mathrm{~mol}^{-1}$ at 37,42 and $47^{\circ} \mathrm{C}$, respectively at $\mathrm{pH}$ 7.0.

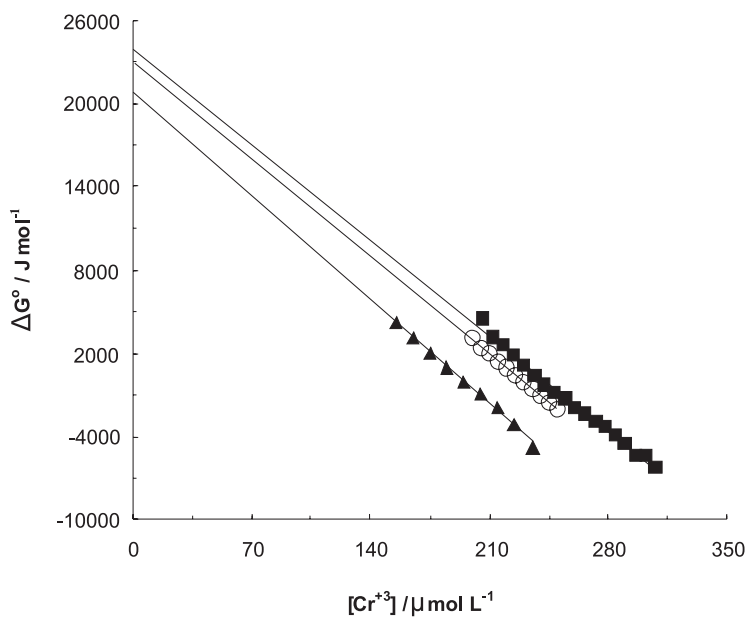

Figure 2. Plot of $\Delta \mathrm{G}^{\circ}$ versus $\left[\mathrm{Cr}^{3+}\right]$ at different temperatures, $37(\bigcirc), 42$

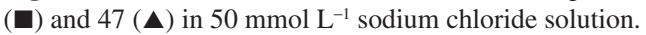

Since BLG at neutral $\mathrm{pH}$ (our experimental conditions) is a dimer and we have calculated the Gibbs free energy of BLG in the presence of different concentrations of $\mathrm{Cr}^{3+}$ at different temperatures (Table 1), then we can conclude that $\mathrm{Cr}^{3+}$ ions can induce the dissociation of the subunits in dimeric form of BLG at different temperatures. Regarding to these data, we used other techniques (far- and near-UV CD and fluorescence spectroscopy) that are capable of sensing different structural properties of the BLG-A at different temperatures in the presence and absence of $\mathrm{Cr}^{3+}$ ion.

\section{Fluorescence measurements}

Fluorescence spectroscopy is an useful technique to study the structure, dynamics and binding properties of protein molecules in solution. The intrinsic fluorescence of tryptophanyl residues is a particularly sensitive method to perform this kind of studies. BLG has two tryptophanyl residues. From the Papiez et al. ${ }^{29}$ crystal structure, Trp19 is at the base of the central hydrophobic calyx of the protein, while Trp 61 is part of an external loop. The intrinsic fluorescence of BLG is then almost exclusively attributed to $\operatorname{Trp} 19$, positioned in a more apolar environment than Trp $61 .{ }^{29}$ Figure 3 (A-D) shows the effect of the midpoint concentration of $\mathrm{Cr}^{3+}$ on the intrinsic Trp fluorescence of BLG-A at different temperatures $\left(27,37,42\right.$ and $\left.47^{\circ} \mathrm{C}\right)$. It is seen in this figure that the addition of $\mathrm{Cr}^{3+}$ induces a decrease (approximately 6\%) at $27{ }^{\circ} \mathrm{C}$ (Figure 3A) and an increase at other temperatures of 37,42 and $47{ }^{\circ} \mathrm{C}$ (Figure B, C and D) in the emission of the native BLG. Figure $3 \mathrm{E}$ shows the effects of the temperature $\left(27^{\circ} \mathrm{C}\right.$ to $47^{\circ} \mathrm{C}$ ) on intrinsic fluorescence of the native BLG-A. It

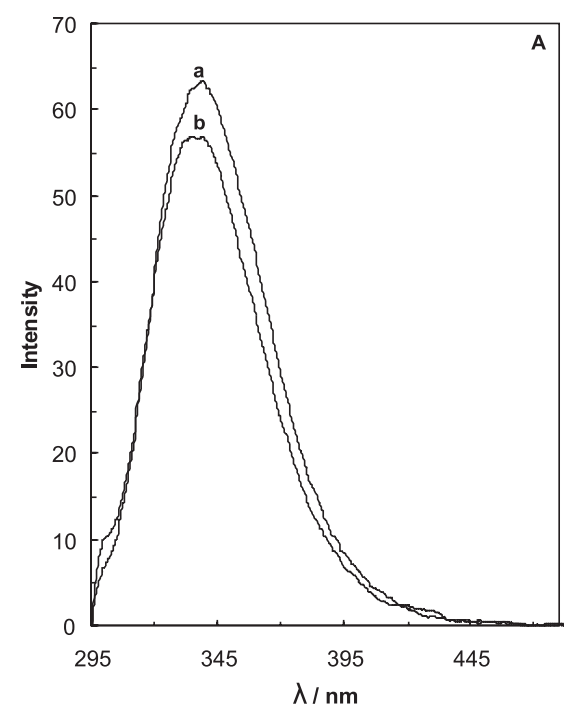

Figure 3A. The effect of midpoint concentration of $\mathrm{Cr}^{3+}$ ion on the intrinsic fluorescence of BLG-A $\left(5 \mu \mathrm{mol} \mathrm{L}^{-1}\right)$ in $50 \mathrm{mmol} \mathrm{L}^{-1}$ sodium chloride solution $(\mathrm{pH} 7.0)$ at $27^{\circ} \mathrm{C}$. $\left[\mathrm{Cr}^{3+}\right]=0$ (a) and $\left[\mathrm{Cr}^{3+}\right]=224.2 \mu \mathrm{mol} \mathrm{L}^{-1}$ (b). 


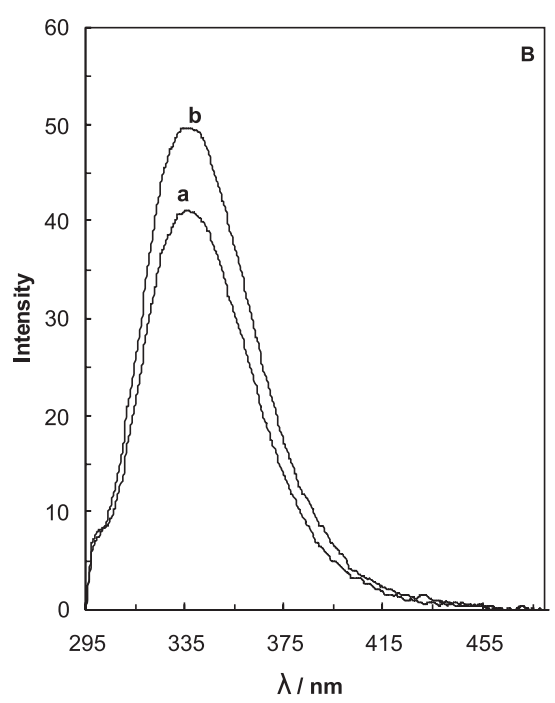

Figure 3B. The effect of midpoint concentration of $\mathrm{Cr}^{3+}$ ion on the intrinsic fluorescence of BLG-A $\left(5 \mu \mathrm{mol} \mathrm{L}^{-1}\right)$ in $50 \mathrm{mmol} \mathrm{L}^{-1}$ sodium chloride solution (pH 7.0) at $37^{\circ} \mathrm{C}$. $\left[\mathrm{Cr}^{3+}\right]=0$ (a) and $\left[\mathrm{Cr}^{3+}\right]=130.3 \mu \mathrm{mol} \mathrm{L}^{-1}$ (b) .

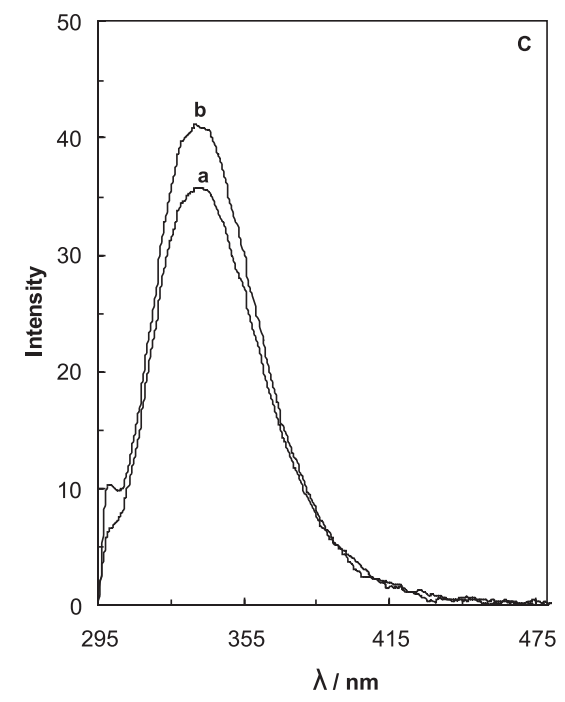

Figure 3C. The effect of midpoint concentration of $\mathrm{Cr}^{3+}$ ion on the intrinsic fluorescence of BLG-A $\left(5 \mu \mathrm{mol} \mathrm{L}^{-1}\right)$ in $50 \mathrm{mmol} \mathrm{L}^{-1}$ sodium chloride solution ( $\mathrm{pH} 7.0$ ) at $42{ }^{\circ} \mathrm{C} .\left[\mathrm{Cr}^{3+}\right]=0$ (a) and $\left[\mathrm{Cr}^{3+}\right]=72.7 \mu \mathrm{mol} \mathrm{L}^{-1}$ (b).

is seen in this figure that an increase in temperature can significantly reduce the intrinsic fluorescence of the native BLG-A (approximately 51\%). Hence; it can be concluded that the tertiary structure of BLG is altered on heating. It has been reported that Trp 61 has a minor contribution to the overall fluorescence emission of BLG. ${ }^{30}$ This can be due to the location of Trp 61 near a disulfide bond (Cys 66 and 160) or near the guanidine group of Arg 124 (3-4 distance from Trp 19) indole ring, ${ }^{22}$ which can quench its emission and/or to the self-quenching of $\operatorname{Trp} 61$ of the other monomer in the BLG dimer form. Also, the position of the emission maximum of the native BLG at $335 \mathrm{~nm}$ is not a characteristic of a completely nonpolar medium, suggesting some contribution to the spectrum of the more

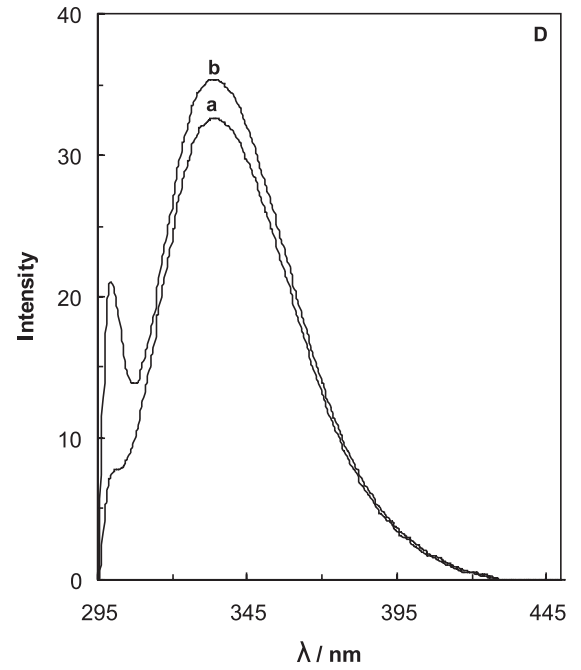

Figure 3D. The effect of midpoint concentration of $\mathrm{Cr}^{3+}$ ion on the intrinsic fluorescence of BLG-A $\left.(5 \mu \mathrm{mol} \mathrm{L})^{-1}\right)$ in $50 \mathrm{mmol} \mathrm{L}^{-1}$ sodium chloride solution ( $\mathrm{pH} \mathrm{7.0)}$ at $47{ }^{\circ} \mathrm{C}$. $\left[\mathrm{Cr}^{3+}\right]=0$ (a) and $\left[\mathrm{Cr}^{3+}\right]=36.8 \mu \mathrm{mol} \mathrm{L}^{-1}$ (b).

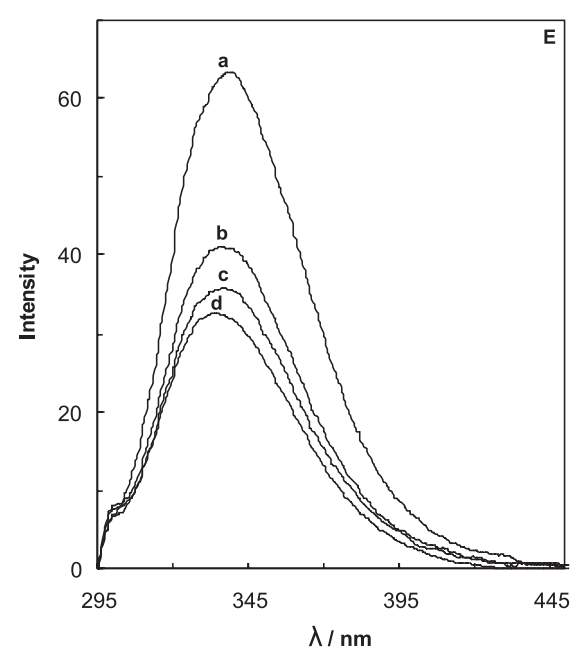

Figure 3E. The effect of different temperatures on the intrinsic fluorescence of BLG-A $\left.(5 \mu \mathrm{mol} \mathrm{L})^{-1}\right)$ in $50 \mathrm{mmol} \mathrm{L}^{-1}$ sodium chloride solution (pH 7.0) at 27 (a), 37 (b), 42 (c) and $47^{\circ} \mathrm{C}(\mathrm{d})$.

surface exposed Trp-61. The observation that fluorescence intensity decreases on increasing the temperature ( 27 up to $47^{\circ} \mathrm{C}$ ) might be due to the changing environment of Trp 19 (Figure 3E).

Is the calyx structure of the native BLG in the presence of $\mathrm{Cr}^{3+}$ ion slightly loosed on heating? In order to answer this question, we use ANS fluorescence intensity measurements in our studies. The ANS is a molecule that shares both hydrophilic and hydrophobic characters and whose fluorescence response appears as a convenient and sensitive tool apt to investigate the nature of proteins binding regions. Small, albeit significant, changes in ANS fluorescence, when changing the protein environment, appear to reflect a modified ligand-protein interaction, 
which can be due to changes in the probe response. ${ }^{31}$ ANS is frequently used to demonstrate the presence of partially unfolded conformations of globular proteins. This is because ANS binds to solvent-exposed hydrophobic clusters, which results in a considerable increase in ANS fluorescence intensity and in a blue shift of the fluorescence emission maximum..$^{32}$ Figure 4 (A-D) shows the ANS spectra in the presence of midpoint concentration of $\mathrm{Cr}^{3+}$ and the absence of it on BLG-A at different temperatures. It can be seen that $\mathrm{Cr}^{3+}$ considerably enhances the ANS fluorescence intensity of the protein at all temperatures except at $47^{\circ} \mathrm{C}$ (the emission of ANS in the absence and presence of $\mathrm{Cr}^{3+}$ ions does not show any change). $\mathrm{Cr}^{3+}$ ions induce a pronounced blue shift ( $\mathrm{ca} .3$ in $27^{\circ} \mathrm{C}$ to $\mathrm{ca} .7 \mathrm{~nm}$ in 37 and $42^{\circ} \mathrm{C}$ ) in the $\lambda_{\text {max }}$ of ANS. Hence, binding of chromium ions leads to a partially unfolding in the protein resulted from solvent-exposed hydrophobic patches.
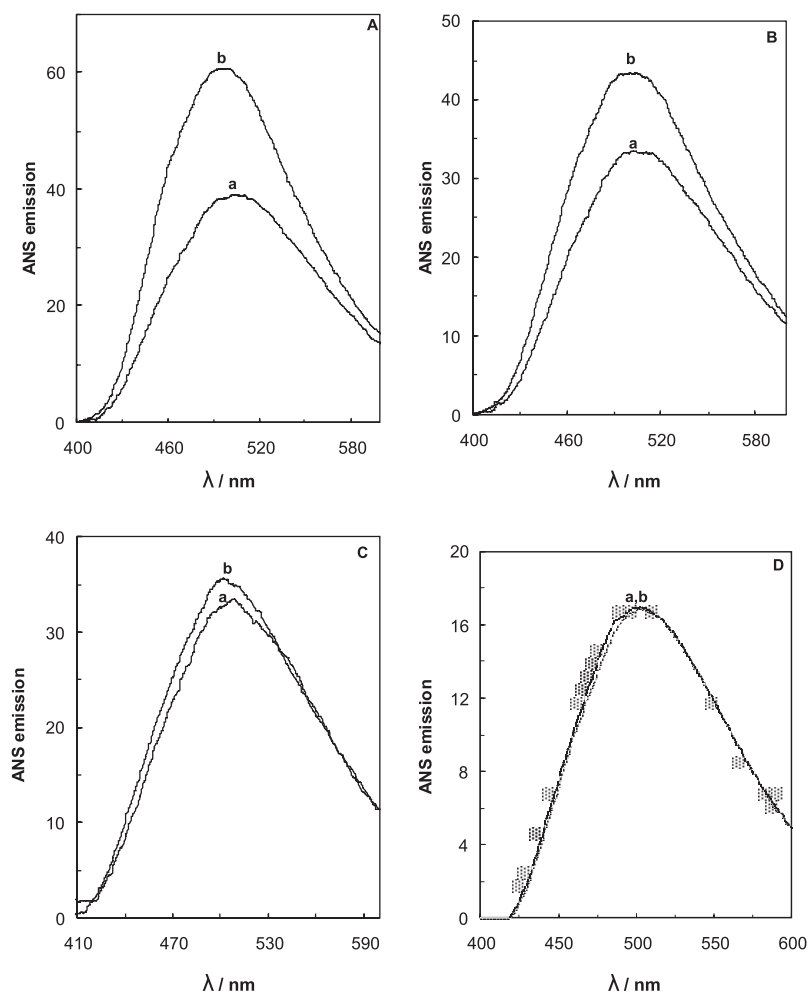

Figure 4. ANS fluorescence spectra measured of $5 \mu \mathrm{mol} \mathrm{L}{ }^{-1}$ BLG-A (a) and BLG-A $(5 \mu \mathrm{mol} \mathrm{L}-1)$ incubated with midpoint concentration of $\mathrm{Cr}^{3+}$ (b) at $27{ }^{\circ} \mathrm{C}(\mathrm{A}), 37{ }^{\circ} \mathrm{C}(\mathrm{B}), 42{ }^{\circ} \mathrm{C}(\mathrm{C})$ and $47{ }^{\circ} \mathrm{C}$ (D) in $50 \mathrm{mmol} \mathrm{L}{ }^{-1}$ sodium chloride solution.

\section{Far-UV CD measurements}

$\mathrm{CD}$ has proved to be an ideal technique for monitoring conformational changes in proteins, which can occur as a result of changes in experimental parameters such as
$\mathrm{pH}$, temperature and binding of ligands. ${ }^{22}$ The far-UV CD spectra characterize the secondary structure of proteins due to the peptide bond absorption. The CD spectrum of BLG is typical of a protein that is composed of antiparallel $\beta$-structure and shows a minimum at $217 \mathrm{~nm} .{ }^{33}$ The farUV CD spectra of BLG-A at different temperatures in the absence and in the presence of midpoint concentrations of $\mathrm{Cr}^{3+}$ ions $\left(605 \mu \mathrm{mol} \mathrm{L} \mathrm{L}^{-1}\right.$ for $27^{\circ} \mathrm{C}, 352 \mu \mathrm{mol} \mathrm{L}^{-1}$ for $37^{\circ} \mathrm{C}$,

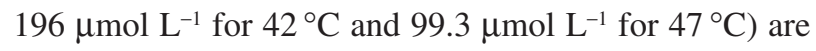
shown in Figures $5 \mathrm{~A}$ and $\mathrm{B}$, respectively. Increasing of the temperature from $27^{\circ} \mathrm{C}$ to $47^{\circ} \mathrm{C}$ (in the absence and presence of $\mathrm{Cr}^{3+}$ ions) does not show any significant changes in the content of regular secondary structure of the BLG-A.
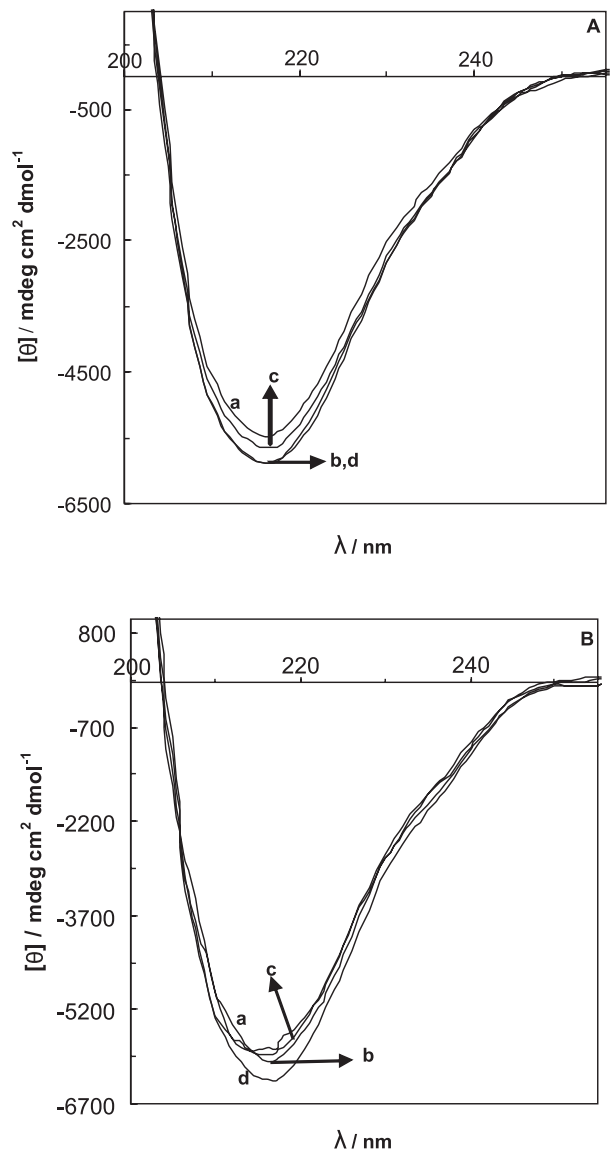

Figure 5. The far-UV CD spectrum of BLG-A at different temperatures of 27 (a), 37 (b), 42 (c) and $47^{\circ} \mathrm{C}$ (d) in the absence (A) and in the presence (B) of midpoint concentrations of $\mathrm{Cr}^{3+}$ ions: $605 \mu \mathrm{mol} \mathrm{L}^{-1}$ for $27^{\circ} \mathrm{C}$ (a), $352 \mu \mathrm{mol} \mathrm{L}{ }^{-1}$ for $37^{\circ} \mathrm{C}$ (b), $196 \mu \mathrm{mol} \mathrm{L}^{-1}$ for $42^{\circ} \mathrm{C}$ (c) and $99.3 \mu \mathrm{mol} \mathrm{L}-1$ for $47^{\circ} \mathrm{C}(\mathrm{d})$.

\section{Near-UV CD measurements}

The near-UV CD of proteins arises from the environments of each aromatic amino acid side chains as well as possible contributions from disulphide bonds, or non-protein cofactors, which might absorb in this spectral region and 
thus gives information about the tertiary structure of the protein. ${ }^{33}$ The near-UV CD spectrum of BLG alone shows a pattern of negative peaks between 260 and $320 \mathrm{~nm}$ (Figure 6A) due to the presence of aromatic residue: two tryptophans (Trp19 and 61), four tyrosines (Tyr 20, 42, 99 and 102) and four phenylalanines (Phe 82, 105, 136 and 151). Although all of them can contribute to the CD spectrum, Trp residues are often the major determinants of the near-UV CD curve, Trp signals are generally more intense than those of Tyr and Phe and they occur between 250 and $300 \mathrm{~nm}$, whereas Phe and Tyr usually do not absorb above $270 \mathrm{~nm}$ and $290 \mathrm{~nm}$, respectively. ${ }^{22,33-35}$ According to this, the negative bands at $293 \mathrm{~nm}$ and $285 \mathrm{~nm}$ can be assigned to asymmetrically perturbed tryptophans while peaks below $280 \mathrm{~nm}$ are likely the result of the chiral environment of Phe and Tyr residues. ${ }^{35}$ The near-UV CD spectrum of BLG-A at different temperatures in the absence and in the presence of midpoint concentrations of $\mathrm{Cr}^{3+}$

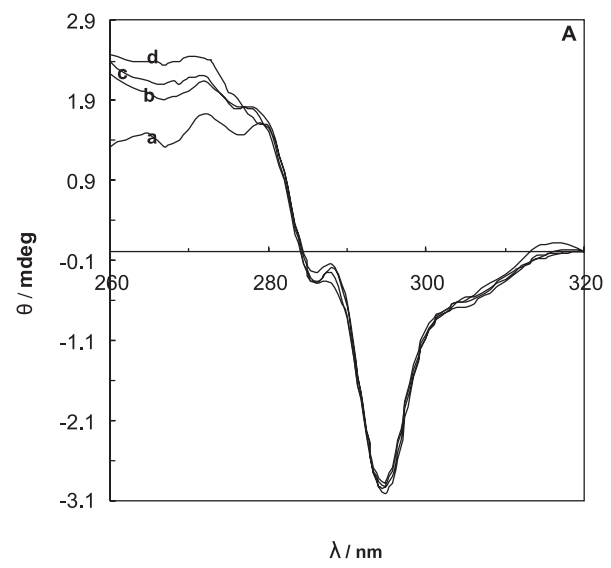

Figure 6A. Near-UV circular dichroism spectra of $57 \mu \mathrm{mol} \mathrm{L} \mathrm{L}^{-1}$ BLG-A measured at different temperatures of 27 (a), 37 (b), 42 (c) and $47^{\circ} \mathrm{C}$ (d) in $50 \mathrm{mmol} \mathrm{L}^{-1}$ sodium chloride solution.

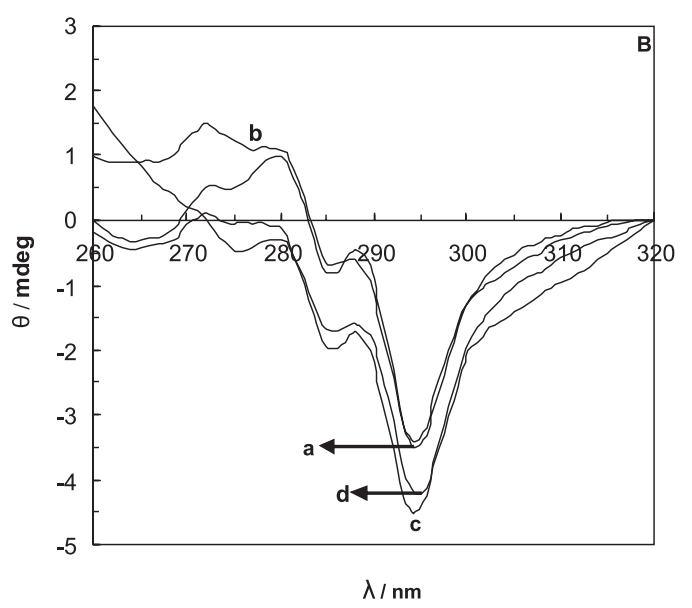

Figure 6B. Near-UV circular dichroism spectra of $57 \mu \mathrm{mol} \mathrm{L}{ }^{-1}$ BLG-A incubated with different midpoint concentrations of $\mathrm{Cr}^{3+}$ at 27 (a), 37 (b), 42 (c) and $47^{\circ} \mathrm{C}$ (d) in $50 \mathrm{mmol} \mathrm{L}^{-1}$ sodium chloride solution. ions $\left(2.55 \mathrm{mmol} \mathrm{L}-1\right.$ for $27^{\circ} \mathrm{C}, 1.48 \mathrm{mmol} \mathrm{L}-1$ for $37^{\circ} \mathrm{C}$, $0.42 \mathrm{mmol} \mathrm{L}{ }^{-1}$ for $42^{\circ} \mathrm{C}$ and $0.063 \mathrm{mmol} \mathrm{L}^{-1}$ for $47^{\circ} \mathrm{C}$ ) are shown in Figure 6A and 6B. Figure 6A shows that an increase in temperature does not cause any considerably change in the $[\theta]_{293}$ and $[\theta]_{285}$ values, but causes significance decrease in $[\theta]_{275}$. The significance decrease in $[\theta]_{275}$ means that the position of Tyr residues of protein can change and move into less hydrophobic environment on increasing the temperature, ${ }^{35}$ and BLG-A undergoes a conformational transition affecting its tertiary structure. Since the decrease in fluorescence emission on increasing the temperature might be due to a change in the environment of Trp19 which is located near the Tyr 20, it may be concluded that a change in the structure of calyx (Trp 19 environment) may affect the adjacent residue (Tyr 20) and move it into a less hydrophobic environment (Figure 7). From these data, it seems that the significance decrease in $[\theta]_{275}$ of the BLG-A probably resulted from the changing in the location of Tyr 20. The near-UV CD spectrum of BLG-A at different temperatures in the presence of midpoint concentrations of $\mathrm{Cr}^{3+}$ ions shows considerable changes in $[\theta]_{293},[\theta]_{285}$ and $[\theta]_{275}$ (Figure $6 \mathrm{~B}$ ), suggesting a change in the tertiary structure of the protein.

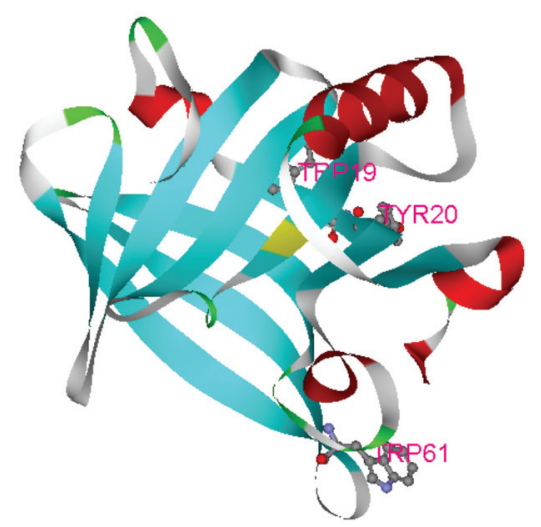

Figure 7. Representation of the 3-D structure of the of $\beta$-lactoglobulin-A and the position of aromatic aminoacids of Trp19 and 61 and Tyr 20 in ribbon model. (This figure has been drawn using WebLab ViewerPro Software 4.0. Software downloaded and PDB code: 1QG5).

The change in the mean residue ellipticity of BLG in the absence and presence of different concentrations of $\mathrm{Cr}$ (III) (the concentrations equivalent to midpoint concentrations of $\mathrm{Cr}^{3+}$ ions at $27,37,42$ and $47^{\circ} \mathrm{C}$ ) at $293 \mathrm{~nm}$ as a function of temperature in the range, $25-100^{\circ} \mathrm{C}$ is shown in Figure 8. The melting points $\left(\mathrm{T}_{\mathrm{m}}\right)$ are listed in Table 1 . This table shows that high concentrations (equivalent to midpoint concentrations of 27,37 and $42{ }^{\circ} \mathrm{C}$ ) of $\mathrm{Cr}^{3+}$ ions can reduce the thermal stability of the BLG-A, whereas in the lowest concentration (equivalent to midpoint concentration of $47^{\circ} \mathrm{C}$ ) can increase the thermal stability of the protein. 


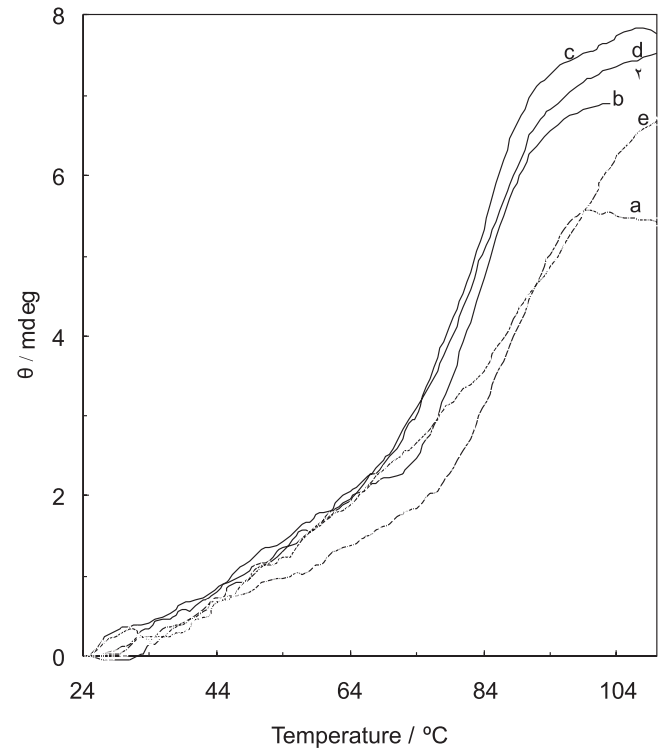

Figure 8. Effect of temperature on the mean residue ellipticity at 293 (mdeg) for the native BLG-A (in the absence of $\mathrm{Cr}^{3+}$ ion), BLG-A after 3 min incubation with midpoint concentrations of $\mathrm{Cr}^{3+}$ at 27 (b), 37 (c), 42 (d) and $47^{\circ} \mathrm{C}$ (e) in $50 \mathrm{mmol} \mathrm{L}^{-1}$ sodium chloride solution. The protein concentration was $57 \mu \mathrm{mol} \mathrm{L}^{-1}$.

\section{Conclusions}

The above results on BLG in the absence and in the presence of $\mathrm{Cr}^{3+}$ ions at different temperatures allow to conclude that an increase in temperature does not perturb the secondary structures of the protein, but significantly alters its tertiary structure.

\section{Acknowledgements}

The financial supports of the Research Council of University of Tehran and the Iran National Science Foundation (INSF) are highly appreciated.

\section{References}

1. Hong, Y. H.; Creamer, L. K; Int. Dairy J. 2002, 12, 345.

2. Medrano, A.; Abirached, C.; Panizzolo, L.; Moyna, P.; Añón, M.C; Food. Chem. 2009, 113, 127.

3. Townend, R; Acta. Biochem. Biophys. 1965, 109, 1.

4. Wit, J.N; Trends Food. Sci. Technol. 2009, $20,27$.

5. Divsalar, A.; Saboury, A.A.; Moosavi- Movahedi, A.A.; Mansoori-Torshizi, H; Int. J. Biol. Macromol. 2006, 38, 9.

6. Brown, E. D; J. Dairy Sci. 1984, 67, 713.

7. Dodin, G.; Andrieux, M.; Al Kabbani, H; Eur. J. Biochem. 1990, 193, 697
8. Dufour, E.; Haertle, T; J. Agric. Food. Chem. 1990, 38, 1691.

9. Farrel, H. M.; Behe, M. J.; Enyart, J. A; J. Dairy Sci. 1987, 70, 252.

10. Ono, J.; Doi, K.; Nagasawa, T; Agric. Biol. Chem. 1975, 39, 2149.

11. Powell Baker, H.; Saroff, H. A; Biochemistry 1965, 4, 1670.

12. Lu, Y.; Valentine, J. S; Curr. Opin. Struct. Biol. 1997, 7, 495.

13. Myers, J. M.; Antholine, W. E.; Myers, C. R; Toxicology 2008 , 246, 222.

14. Shirvastava, R.; Upretic, R. K.; Chaturvedi, U. C; FEMS Immunol. Med. Microbiol. 2002, 34, 1.

15. Tamblyn, L.; Li, E.; Sarras, H.; Srikanth, P.; Hande, M. P.; McPherson, J. P; Mutat. Res. 2009, 660, 57.

16. Gayatari, R.; Sharma, A. K.; Rajarm, R.; Ramasami, T; Biochem. Biophys. Res. Com. 2001, 283, 229.

17. Anderson, R.A; Diabetes Metab. 2000, 26, 22.

18. Divsalar, A.; Saboury, A.A;. Moosavi-Movahed, A.A; Protein J. 2006, 25, 157.

19. Brownlow, S.; Cabral, J. H. M.; Cooper, R.; Flower, D. R.; Yewdall, S. J.; Polikarpov, I.; North, A. C. T.; Sawyer, L; Structure 1997, 5, 481.

20. Manavalan, P.; Johnson, C .J. R; Anal. Biochem. 1987, 167, 76.

21. Yang, J. T.; Wu, C. S. C.; Martinez, H. M; Methods Enzymol. 1986, 130, 208.

22. Viseu, M. I.; Carvalho, T. I.; Costa, S. M. B; Biophys. J. 2004, 86, 2392.

23. Pace, C. N; TibTech. 1990, 8, 93.

24. Saboury, A. A.; Moosavi-Movahedi, A. A; Biochem. Educ. 1995, 23, 164 .

25. Moosavi-Movahedi, A. A.; Nazari, K.; Saboury, A. A; Colloids Surf., B 1997, 9, 123.

26. Ahmad. F; J. Iran. Chem. Soc. 2004, 1, 99.

27. Pace, C. N.; Shiley, B. A.; Thomson, J. A; In Protein Structure - $a$ Practical Approach, Creighton T. Eed.; IRL Press: Oxford, 1990.

28. Apenten, P. K. O.; Khokhar, S.; Galani, D; Food Hydrocolloids 2002, 16, 95 .

29. Oliveira, K. M. G.; Valente-Mesquita, V. L.; Botelho, M. M.; Sawyer, L.; Ferreira, S. T.; Polikarpov, I; Eur. J. Biochem. 2001, $268,477$.

30. Zsila, F.; Imre, T.; Szabo, P. T.; Bikadi, Z.; Simonia, M; FEBS Lett. 2002, 520,81 .

31. Creamer, L.K; Biochemistry 1995, 34, 7170.

32. Matulis, D.; Baumann, C. G.; Bloomfield, V. A.; Lovrien, R. E; Biopolymers 1999, 49, 451.

33. Uversky, V. N.; Li, J.; Fink, A. L; J. Biol. Chem. 2001, 47, 44284.

34. Kelly, S. M.; Price, N. C; Biochem. Biophys. Acta 1997, 1338, 161.

35. Kelly, S. M.; Price, N. C; Curr. Protein Pept. Sci. 2000, 1, 349.

Received: November 25, 2008 Web Release Date: September 28, 2009 